\title{
Evaluating the Implications of Lineaments on Petroleum Fields: South Sumatra, Indonesia
}

\author{
Tapiwa Frank Kwachara Ngoroyemoto, Jarot Setyowiyoto, and Didit Hadi Barianto \\ Department of Geological Engineering, Faculty of Engineering, Universitas Gadjah Mada, Yogyakarta, Indonesia
}

\begin{abstract}
Declining oil prices have reduced petroleum exploration as oil production is no longer a lucrative investment area as in the previous years. Current exploration activities supported by fieldwork are cost-intensive considering the time, personal, and equipment required to delineate prospects. There is a need to develop low-cost methods to delineate areas of potential hydrocarbon resources. This research uses Land Satellite (Landsat) 8 Operational Land Imager (OLI) for extracting petroleum-induced alterations, Shutter Radar Topography Mission (SRTM) for lineament extraction, geological maps to develop a low-cost method of petroleum exploration. The results indicate high hydroxide $(\mathrm{OH})$ bearing alterations on the Gumai and Kasai Formation, a seal rock. Extensional tectonics is responsible for the migration of petroleum from the subsurface. Future exploration is suggested to concentrate on the Gumai and Kasai Formation based on evidence of micro seepage.
\end{abstract}

Keywords: Petroleum · Exploration · Lineaments · GIS · Remote Sensing.

\section{INTRODUCTION}

Petroleum resources are a strategic resource that sustains production and ultimately contributes to many countries' Gross Domestic Product (GDP). Indonesia used to have sufficient oil production to sustain herself and contribute to the Organization of Petroleum Exporting countries (OPEC); however, her status changed from an exporting country to an importing country (CNBC, 2015).

Like many developing countries, a significant challenge in Indonesia is a high population that directly strains resources such as hydrocarbon. To make matters worse, dry wells are experienced during the exploration of green fields. Exploration success can be increased by correlating geological formations such as lineaments with the existing petroleum fields.

In order to restore her former status, exploration of petroleum resources is necessary, al-

\footnotetext{
${ }^{*}$ Corresponding author: J. SETYOWiyoto, Department of Geological Engineering, Universitas Gadjah Mada. Jl. Grafika 2 Yogyakarta, Indonesia. E-mail: jsetyowiyoto@gmail.com
}

though, at present, the downward trajectory of oil prices renders exploration as the process consumes millions. Despite the several benefits of using remote sensing imagery for structural mapping, nostudies have been done on costeffective measures that correlate structures with potential petroleum fields.

In light of these limitations, there is a need to develop cost-efficient methods to restore her to her former glory. Remote sensing and Geographic Information Systems (GIS) will be used in this study to explore hydrocarbons. Landsat 8 Operational Land Imager (OLI), Shutter Radar Topography Mission (SRTM), and ancillary maps are used in this study. These will be used to map out structural elements and correlate them with petroleum fields.

South Sumatra Basin is one of the significant petroleum-producing areas in Indonesia, and as a result, much literature related to stratigraphy and geology has been developed. Therefore, a better understanding of the area has been attained from previous studies. This research focuses on the application of remote sensing and 
GIS to determine areas of potential hydrocarbon accumulations. Hydrocarbon alterations were mapped over the lineaments and were validated by the existing petroleum fields in the study area (Vilde et al., 2020). Figure 1 shows the study area in -the South Sumatra area.

\section{Regional GeOlogy}

\subsection{Stratigraphy}

Megacycles of transgression and regression influence the stratigraphy of the South Sumatra Basin, and this condition was also experienced in Western Indonesia (Barber et al., 2005). It has been outlined in the following sections as the Basement, Lahat Formation, Talang Akar Formation, Gumai Formation, Baturaja Formation, and Telisa Formation. The stratigraphy of South Sumatra is shown in Figure 2.

The basement of the South Sumatra Basin (SSB) is composed of igneous (Mesozoic), metamorphic (Paleozoic and Mesozoic), and sedimentary rocks (Paleozoic and Mesozoic), which are of different compositions (Fedyanto and Sunardi, 2003). It consists of several PreTertiary rocks: granite, metamorphic, metasediment, andesite, dolomite, limestone (Holis and Sappie, 2012). The granite is of the Early Jurassic age, originating from the Post-Triassic suturing event related to Jurrasic-Cretaceous plutonism. Two types of granite exist within the South Sumatra Basin, namely weathered granite and fresh granite. The sedimentary rocks within the South Sumatra Basin include limestone, which is assumed to be part of postmutus sediment. It consists of wackestone to packstone. Other fragments include microcrystalline and rare crystalline bioclast.

The metasediment within the South Sumatra Basin exhibits low-grade metamorphism and quartzite, schist, and phyllite. Two microplates exist in the South Sumatra Basin, is the Malacca Microplate and the Meiengui Microplate. The oldest and least deformed basement is Malacca Microplate, located in the Northern and Eastern parts of the basin. The Mergui Microplate is weaker and located in the Southern part. The Mergui and Malacca Microplateare separated by the Mutus assemblage (Ginger and Fielding, 2005). The overlying Paleozoic and Mesozoic strata were affected by metamorphism, which changed the rock properties (Ginger and Fielding, 2005; Amier, 1991). The age of the Lahat Formation ranges from Eocene to Oligocene age, which is approximately $40-54 \mathrm{Ma}$ (Ekaninggarani and Apricanto, 2011). It consists of volcanoclastic, agglomerate, course sandstone and pediment, finer grain size (Septriandi and Sujarmaitanto, 2010). It is also composed of clay and shales intercalated with tuffaceous sandstones associated with coals and glauconite, reflecting a depositional environment influenced by saline and normal water. The sediments overlie the Pre-Tertiary basement (Ekaninggarani and Apricanto, 2011).

The Lemat Formation sediments were deposited from the late Eocene to the early Oligocene. Sediments within this formation were deposited in gardens and consists of beds of non-marine sandstones, siltstones, and shales (Ekaninggarani and Apricanto, 2011). During the transgressive stage, the Lemat Formation was unconformably deposited on the Lahat Formation and represented the second deposition phase. The Lemat Formation was deposited from Oligocene to Miocene (Amier, 1991; Septriandi and Sujarmaitanto, 2010). The transgressive deposition was influenced by half-graben subsidence (Holis and Sappie, 2012). The deposition environment ranges from fluvial, lacustrine, lagoonal, and shallow marine, and it is associated with subsidence due to thermal sag (Holis and Sappie, 2012). The Lemat Formation possesses channeled greyish brown sandstones, siltstones, and shales. A deposition is predominantly no marine sediments overlain by Baturaja limestone and Gumai shale (Holis and Sappie, 2012). The grain size varies from conglomerates to sandstone, mica, pyrite, and silicified wood. The age of the Talan Akar Formation ranges from late Oligocene to early Miocene (Premonowati, 2011).

The Talang Akar Formation consists of the Gritstone (Grm) member and the Transisi member. The Gritstone member is composed of coarse to very coarse sandstone with shale and siltstone intercalations. It has a thickness of approximately $500 \mathrm{~m}$ and was deposited in a fluvial-deltaic environment. On the other hand, the Transisi member is composed of intercalation of shale with sandstone coal in some parts and other areas marine shales and calcareous 


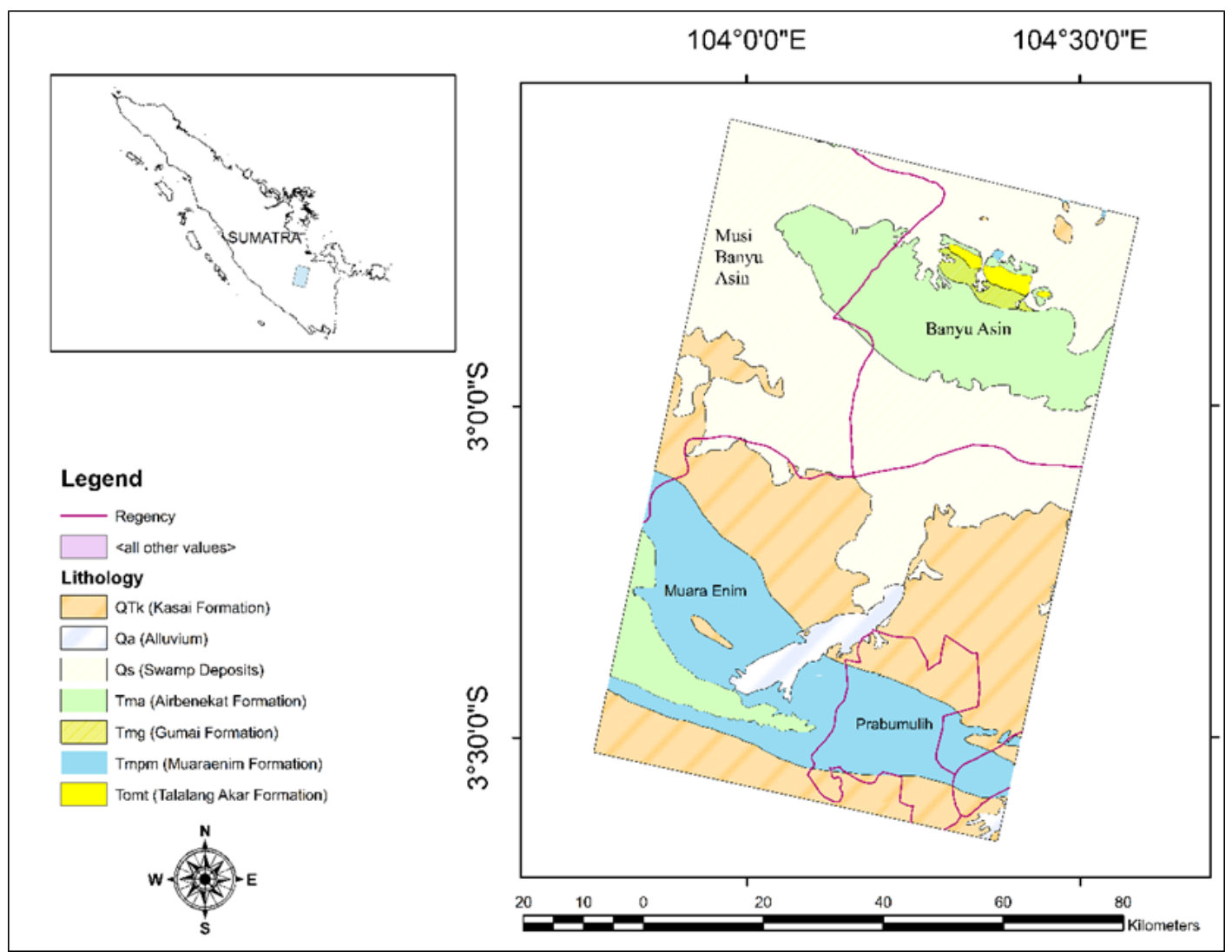

FIGURE 1. Location of the study area within the South Sumatra Basin (Bishop, 2001).

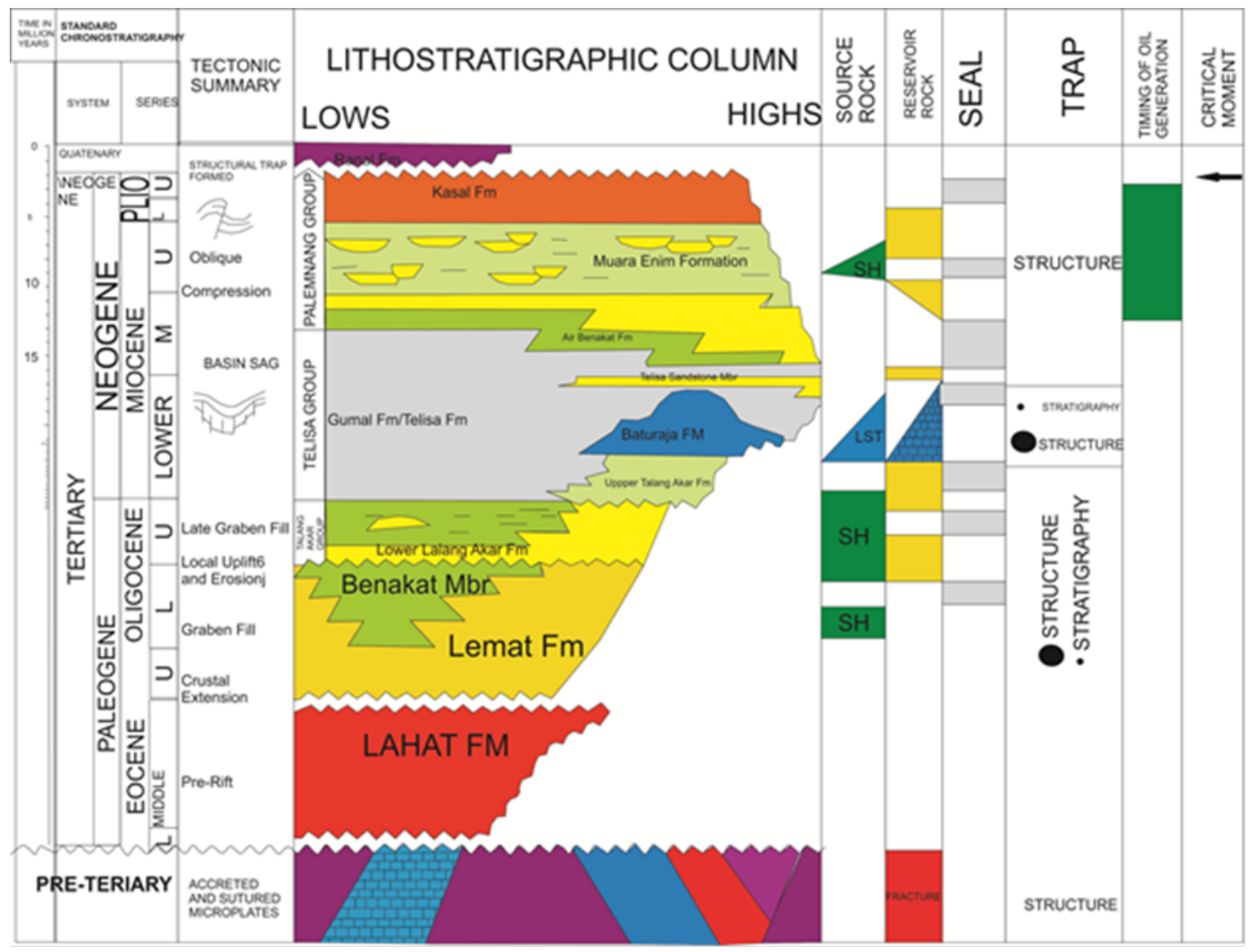

FIGURE 2. Stratigraphy of the South Sumatra Basin (Premonowati, 2011). 
sandstone. It lies conformably on top of the Gritstone member (Septriandi and Sujarmaitanto, 2010). It is also divided into two parts: the Lower Talang Akar Formation and the Upper Talang Formation. The Lower Talang Akar Formation is deposited only in the paleo-lows and can be source rock and reservoir if mature. The Upper Talang Akar Formation is a clastic sedimentary sequence immediately below the Baturaja Formation. It was deposited in the paleo-high. It is younger than the Lower Talang Akar Formation (Ekaninggarani and Apricanto, 2011).

The Batu Raja Formation comprises early Miocene Limestone and Calcareous shale deposited on the platforms at the margins of the basins and as reefs on subtle Intra basinal highs (Ginger and Fielding, 2005). It was conformably deposited upon Pre-Tertiary rocks and consists of shallow marine limestone of reefal facies (Septriandi and Sujarmaitanto, 2010). Carbonate sedimentation in the Batu Raja Formation results from sea level drop, which resulted in exposure and leaching (Fedyanto and Sunardi, 2003). It was well developed on the paleo basement high due to shallow marine waters. Towards the basin lows, lithology of the formation laterally changes to be shales of the Telisa Formation and marl interbedded limestone of the Gumai Formation (Ekaninggarani and Apricanto, 2011). The thickness varies from $60 \mathrm{~m}$ to $520 \mathrm{~m}$ with a thickness of $60-70 \mathrm{~m}$ at the shelf, $60-120 \mathrm{~m}$ at the basement, and $520 \mathrm{~m}$ in Bukit Gerbah (Septriandi and Sujarmaitanto, 2010).

The Gumai Formation represents the late transgressive stage of marine sediments, which occurred during the early to middle Miocene (Septriandi and Sujarmaitanto, 2010). The depositional formation environments range from shallow marine to deep marine depositional environments (Septriandi and Sujarmaitanto, 2010). In the lower Gumai Formation, it was deposited during a transgressive period resulting from half-graben subsidence. In the upper Gumai Formation, the regressive deposition was controlled by regional uplifting controlled by compressive tectonics (Sadarwa and Luthfi, 2005). It is composed of marine shales, siltstones, and sandstones. During the transgression, Gumai Shales dominated the deposition in the entire basin forming a regional seal (Septriandi and Sujarmaitanto, 2010). It intrudes to other formations, allowing hydrocarbons' downward movement along with the seal (Patra et al., 2012). The thickness ranges from 200 to $500 \mathrm{~m}$, although it extends to $1,500 \mathrm{~m}$ in the Lematang depression (Septriandi and Sujarmaitanto, 2010).

The Telisa Formation is Pliocene in age and was deposited in a middle neritic environment. It consists of a shale member and a sandstone member. The sandstone member is composed of very fine to fine-grained sandstone, calcareous, angular to sub-round. The Telisa Formation comprises very well-sorted lithic arenites with lower shales deposited in a shallow marine shoreface during sea-level low stand and transgression. The shale member consists of sandstone interbedded with shale, which was deposited in tidal environments. It has a varying thickness of 20 to 300 feet (Argakoesoemah et al., 2005; Asra and Fiter, 2005).

The Air Benekat Formation comprises middle Miocene sediments whose origins range from fluvial/alluvial, coastal/marginal marine, shallow marine deltaic, and offset deposits (Ariani et al., 2010). It comprises a series of clastic wedges prograded into the subsiding basin sourced from the Barisan Mountains. It was conformably deposited on the Gumai Formation with an average thickness of $600 \mathrm{~m}$. It is overlain by the Muara Enim Formation (Septriandi and Sujarmaitanto, 2010; Ekaninggarani and Apricanto, 2011).

The Muara Enim Formation is from Late Miocene to the Pliocene age. Sediments in this formation were deposited in a regressive sequence resulting from regional uplifting caused by compressional tectonics (Sadarwa and Luthfi, 2005). It is conformably deposited upon the Air Benakat formation. It comprises sandstone, siltstone, carbonaceous claystone, and several coal seams (Ekaninggarani and Apricanto, 2011; Septriandi and Sujarmaitanto, 2010).

The Kasai Formation ranges from the late Miocene to Pliocene (Septriandi and Sujarmaitanto, 2010). The sediments were deposited in a continental environment, and it rests unconformably on Muara Enim Formation. It comprises conglomerate, tuffaceous sandstones, and tuffs with lignite and silicified 
wood (Ekaninggarani and Apricanto, 2011). The conglomerate contains clasts derived from the Pre-Tertiary units and volcanic materials, marking the uplift of the Barisan mountains. This formation marks the end of Neogene's volcanic activity. The thickness varies from $500 \mathrm{~m}$ to $1000 \mathrm{~m}$ (Septriandi and Sujarmaitanto, 2010; Holis and Sappie, 2012).

\subsection{Tectonics regime}

There are two tectonic regimes in the South Sumatra Basin: the extensional regime during late Paleocene to early Miocene forming northtrending grabens filled with Eocene to early Miocene deposits and basement involved compressional regime that formed the anticlines that are the major traps in the area. The extensional regime is followed by extensive subsidence, which resulted in transgressive sediment. NNE-SSW growth faults developed at this time of subsidence with sediment thickness of $3000 \mathrm{~m}$ at the graben side. The sediment deposited formed potential source rock (Sadarwa and Luthfi, 2005). The second regime is the compressional regime. It occurred from Middle Miocene to the present, which is approximately 18 Ma-Present. The subduction of the IndiaAustralian plate was the primary force that resulted in compression. The main compressional influence was from Pliocene to Pleistocene, and the results were WNW-ESE oriented fold and thrust faults (Sadarwa and Luthfi, 2005).

\subsection{Lineaments in the South Sumatra}

Lineaments in South Sumatra have been classified into several groups based on their location, length, and strike. The lineaments were classified to Musi, Lematang, Kepayang, Saka, and Kampung South Coast Lineament, which have directions that range from $\mathrm{N} 275^{\circ} \mathrm{E}-$ $\mathrm{N} 300^{\circ} \mathrm{E}$. Other lineaments were identified in N$\mathrm{S}$ Palembang and Barisan trend. These have been classified as Jurassic to Upper Cretaceous (Pulunggono et al., 1992). Based on the age of origin, the Musi lineament is the oldest, and the Saka trend is the youngest. The Musi and Lematang trend has dated from Jurassic to lower Cretaceous (Pulunggono et al., 1992). In the Jurassic, the Indian plate was moving in an NW-oriented direction related to the subduction of the Indian plate and Sunda plate. The
Saka lineament is oriented in a similar direction as the Indian plate was still in the process of converging on to the Sundaland margin (Pulunggono et al., 1992).

\section{Material and Methods}

The materials used in this study include Shutter Radar Topography Mission (SRTM), Land Satellite (Landsat) 8 Operational Land Imager satellite r, geological maps, Exelis Visual Information Solutions (ENVI), PCI Geomatics, Aeronautical Reconnaissance, and Geographic Information Systems (ArcMap) 10.2.22. The SRTM and Landsat 8 images were downloaded from the USGS (United States Geological Survey) websites. The date of acquisition of the Landsat 8 OLI was 2013-06-20. The path and row are 124 and 62 , respectively.

The images were combined and clipped to the study area, as shown in Figures 3 and 4. Hillshade were created at angles 180, 225, 270, and 315 degrees. Lineaments were extracted from the SRTM satellite image mosaic using the Prewitt and Sobel Edge Filter and classified according to age. The lineaments were overlaid on the geological map, and a correlation was made against the age of the lithology. The lineaments were extracted using both automatic and manual methods.

The Landsat 8 image was imported using the text file into the ENVI software, and radiometric calibration was applied on the multispectral part of the image. After that, an equation was applied to determine the surface reflectance, which is shown below.

$$
\begin{gathered}
(\text { B1 le } 0) * 0+(B 1 \text { ge } 1) * 1+ \\
(B 1 \text { le } 0 \text { and } B 1 \text { lt } 1) * \text { float }(b 1) / 1
\end{gathered}
$$

where: $B 1$ is Band 1, le is less than, ge is greater than or equal, $l t$ is less than, and float is converted to floating-point.

Band ratios were used to extract the alterations, and these are shown in Table 1. The lineaments were overlaid initially on the lineaments, and after that, to validate the alterations, a proximity analysis was made between the petroleum fields and alterations. 


\section{NGOROYEMOTO et al.}

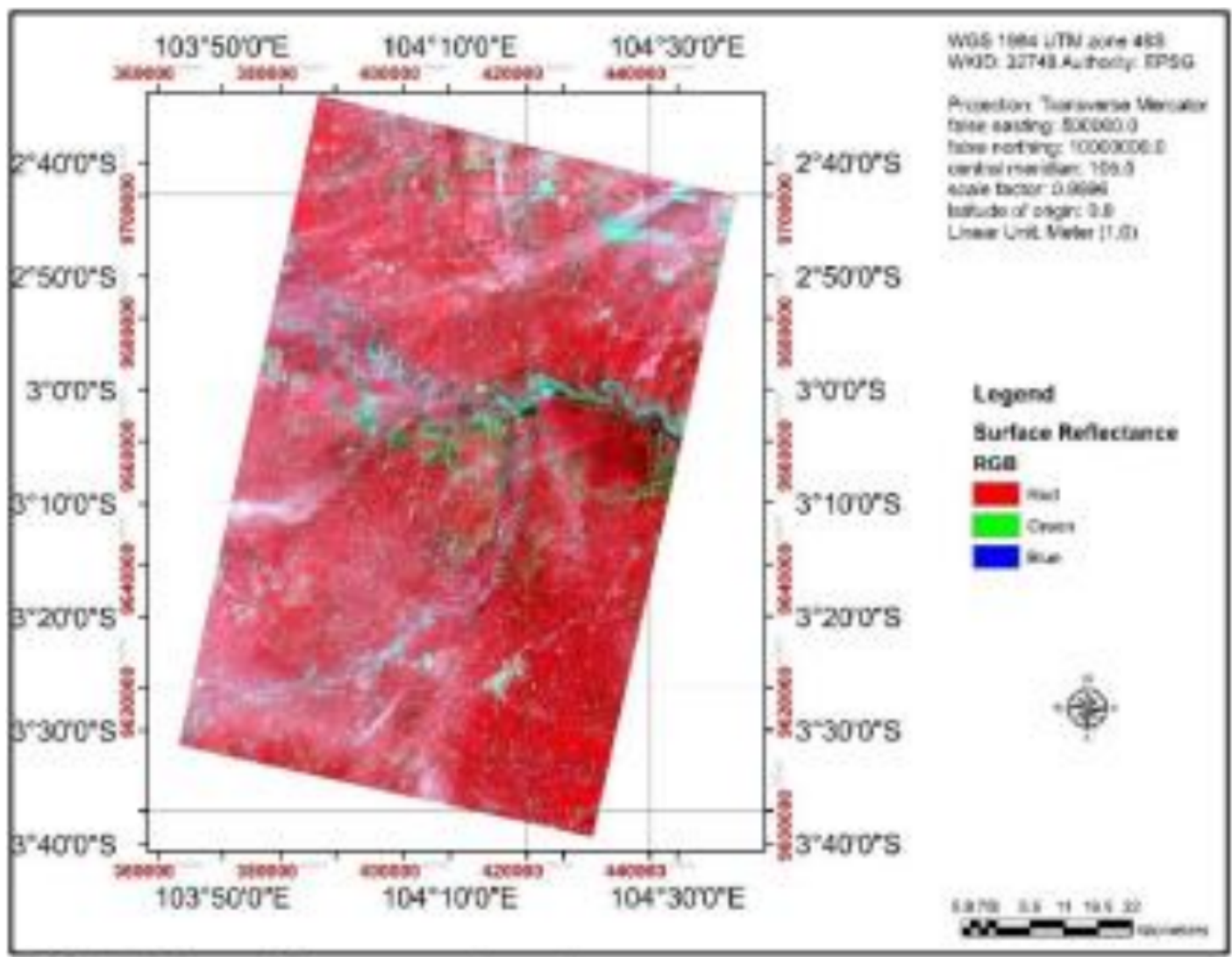

FIGURE 3. Surface Reflectance of the study area that was extracted from Landsat 8 OLI.

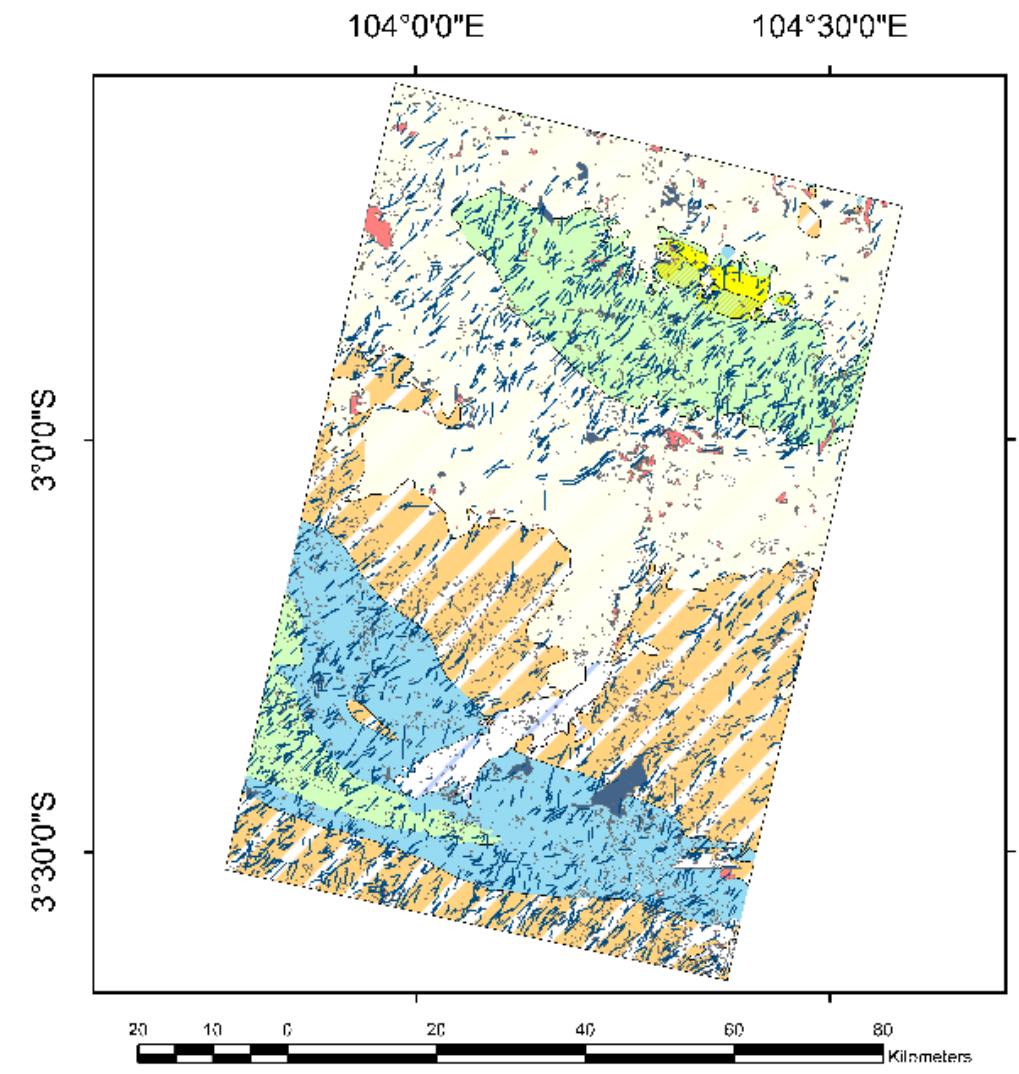

WGS_1984_UTM_Zonc_48S WKID: 32748 Authority: EPSG

Projection: Transwerse_Mercator False_Easting: 500000.0 False_Northing: 1000ududu.0 Central Meridian: 105.0 Scale Factor: 10.9996

Latitude of Origin 0.0

Linear Unil: Meler $\{1.0\}$

\section{Legend}

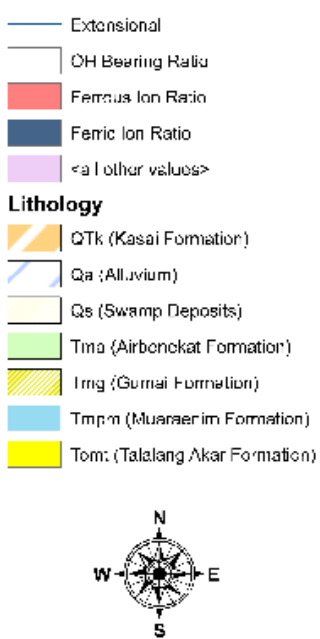

FIGURE 4. Revised Geological Map. 
TABLE 1. Landsat 8 OLI Multispectral Band Ratios to determine the alterations.

\begin{tabular}{lll}
\hline & Band Ratio & Output \\
\hline $\mathrm{R}$ & $\mathrm{B} 4 / \mathrm{B} 1$ & Ferric Ion Ratio \\
$\mathrm{G}$ & $\mathrm{B} 5 / \mathrm{B} 6$ & Ferrous Ion Ratio \\
$\mathrm{B}$ & $\mathrm{B} 6 / \mathrm{B} 7$ & OH Bearing Ratio \\
\hline
\end{tabular}

\section{Results AND Discussion}

Band ratios were used to extracted alterations from the Landsat 8 OLI, and ferric oxide, ferrous oxide, and $\mathrm{OH}$ alterations were mapped out. The predominant alterations are $\mathrm{OH}$. Ferrous ion and ferric ion alterations are absent along the lineaments. The alterations are predominantly located over the middle Miocene lineaments formed during the renewed subduction of the Indian plate beneath the Sunda plate. As a result of the readjustments, hydrocarbons are likely to have been migrated from the subsurface petroleum accumulations within this period based on the age of the lineaments. The $\mathrm{OH}$ bearing alterations indicate the transformation of feldspars to carbonate as the surficial lithology in these areas is alluvial and sandstone with no previous evidence of carbonate minerals. Lineaments formed during the extension regime increased the porosity and promoted the migration of the hydrocarbons from the subsurface.

When a 2000 meter buffer was performed on the existing petroleum fields and an intersection operation was performed, there was a high correlation between the existing petroleum fields and existing alterations even though the petroleum fields are represented as a point covering a few meters. They usually cover several kilometers, as shown in Table 2. There are limited carbonate alterations in the proximity of the petroleum fields and, on the other hand, a much higher correlation with the ferric and ferrous oxide alterations. Based on the evidence provided in Table 2, lineaments are important in the exploration of petroleum resources.

The extensional lineaments, which result from the formation of rift systems are shown in Figure 5, are oriented in a NE-SW direction. These lineaments cut across The Gumai Formation, The Talang Akar Formation, and The Air Benekat Formation providing a pathway
TABLE 2. The frequency of the Petroleum fields within the spatial vicinity of alterations.

\begin{tabular}{ccccccc}
\hline & & \multicolumn{5}{c}{ Buffer $(\mathrm{m})$} \\
\hline & & 0 & 500 & 1000 & 1500 & 2000 \\
\hline \multirow{2}{*}{ Band } & B4/B1 & 2.04 & 4.08 & 6.12 & 84.67 & 91.84 \\
Ratio & B5/B6 & 0 & 0 & 10.2 & 16.33 & 20.41 \\
& B6/B7 & 2.04 & 4.08 & 6.12 & 12.24 & 12.24 \\
\hline
\end{tabular}

for leaking hydrocarbons as illustrated below and, as a result, microhydrocarbon seepage is present on the surface in the form of alterations. Extensional lineaments are present from the oldest formation up until the youngest formation. In the areas of dense lineament distribution as the southern part of the Kasai formation shown in Figure 6, no petroleum fields are existing in those areas. They are only located in sparse lineaments. Lineaments promote the migration of hydrocarbons from cap rock, which is supposed to seal the petroleum system. Therefore, targets for petroleum exploration must be located in areas of least lineament density. Extensional lineaments primarily responsible for the formation of grabens have been observed on both older and younger lithologies. Thus they have promoted migration of hydrocarbons from the oldest formation Talang Akar Formation which has a dual role as source rock and reservoir, to the youngest formation.

\section{CONCLUSION}

Hydrocarbon-induced alterations were determined along the lineaments. The alterations indicate a structural controlled petroleum system with the upward migration of petroleum along the lineaments induced by an enhancement of porosity during the extensional regime. The extensional lineaments resulted in the destruction of the cap rocks, especially the Gumai Formation and Kasai Formation, along a NE-SE direction, and alterations are the result. It is recommended that future exploration be concentrated in areas near $\mathrm{OH}$ bearing alterations, including the Muara Enim formation and alluvial deposits as solid evidence of the hydrocarbon. The hydrocarbon-induced alterations exhibited by ferric ion and ferrous are concentrated along with these areas; however, there have been minimal exploration efforts within these areas. 
WGS_1984_UTM_Zone_48S WKID: $327 \overline{48}$ Authority: EPSG False_Easting: 500000 .0 Central_Meridian: 105.0

Latitude Of Origin: 0.0

Linear Unit: Meter $(1.0)$

\section{Legend}

\section{- Extensional $\square$ <all other values $>$} Lithology

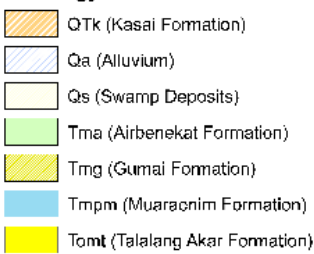

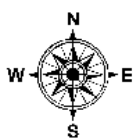

Projection: Transverse_Mercato False_Northing: 10000000.0 Scale_Factor: 0.9996

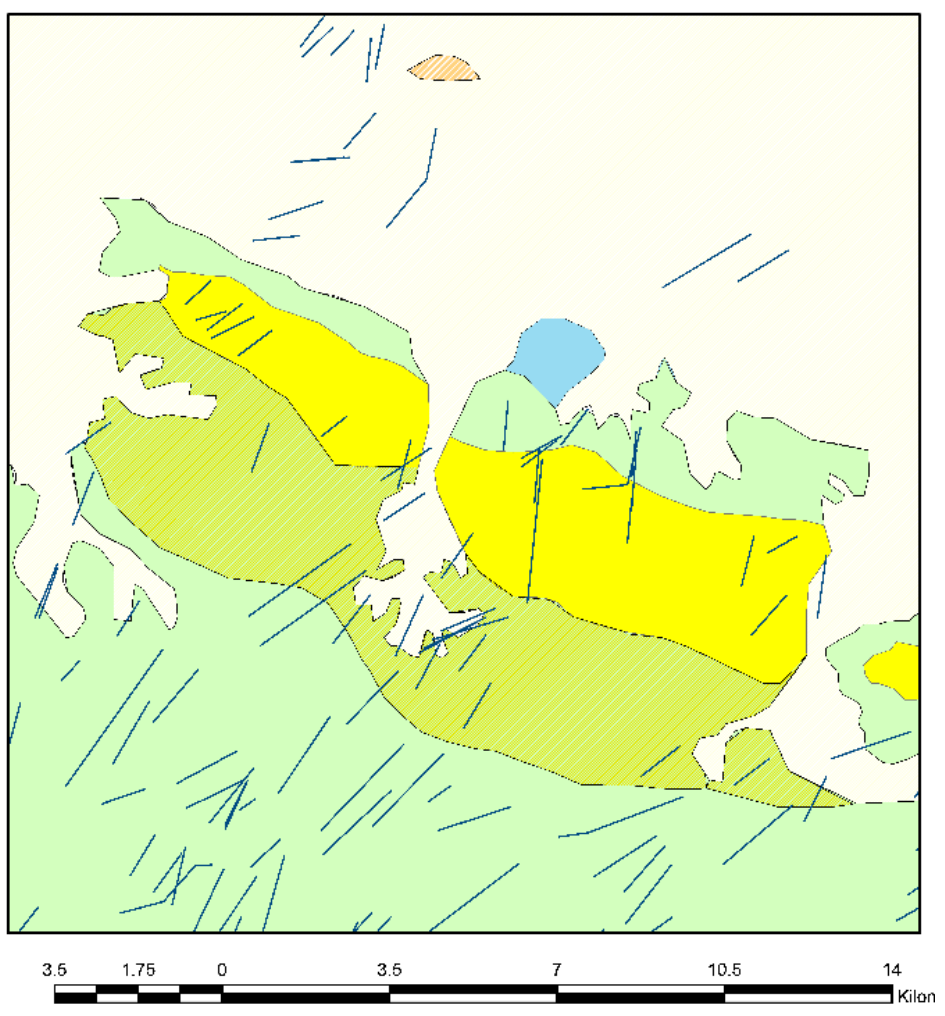

FIGURE 5. Extensional lineaments on the Gumai Formation.

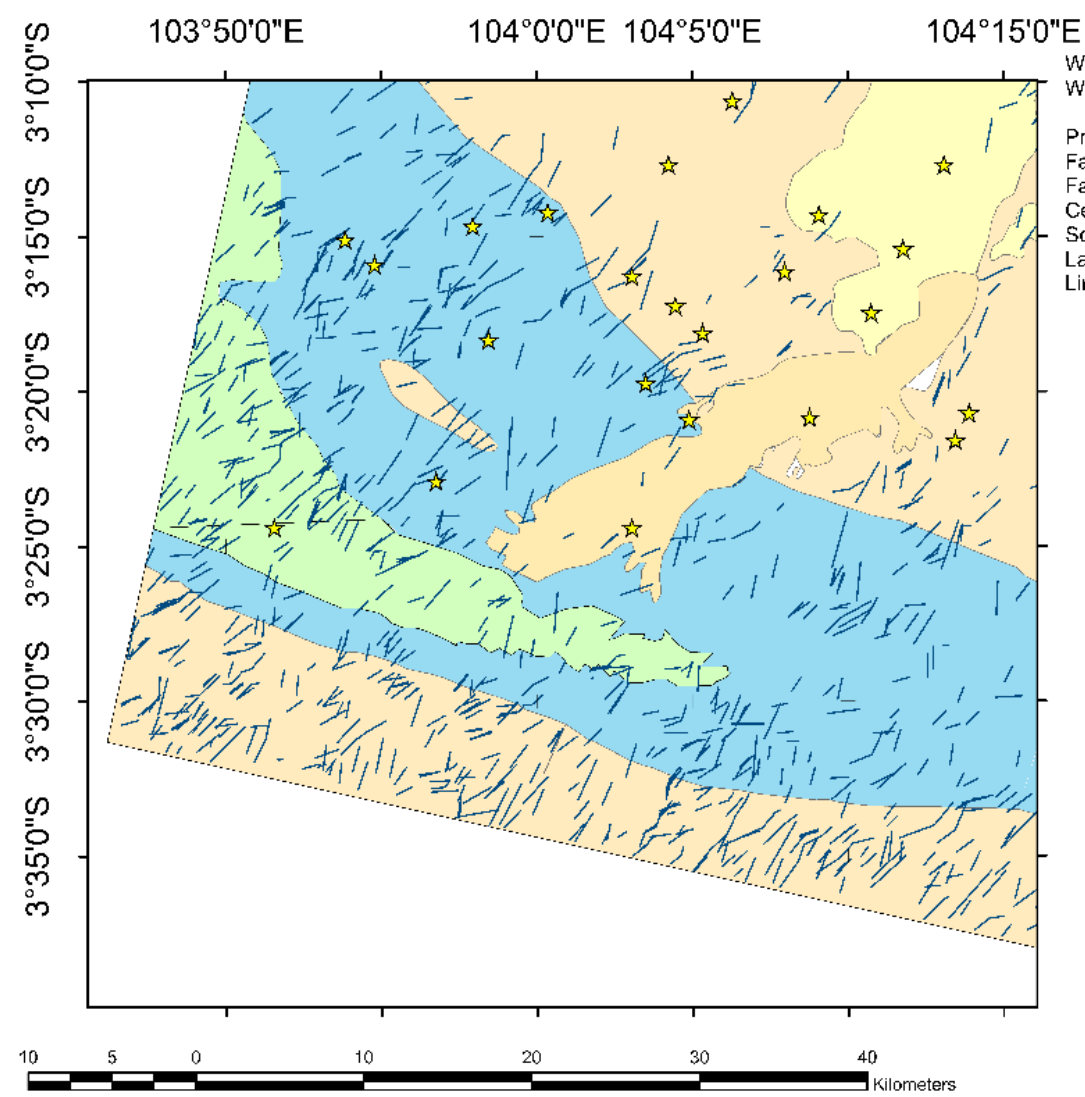

WGS 1984 UTM Zone 48S WKID: 32748 Authority: EPSG

Projection: Transverse Mercator False Easting: 500000.0 False Northing: 10000000 Central Meridian: 105.0 Scale Factor: 0.9996 Latitude Of Origin: 0.0 Linear Unit: Meter (1.0)

\section{Legend}

s) Petroleum Fields Extensional Lineaments Ferric Ion Ratio Study Area <all other values>

Litholog_1

QTk (Plincene)

Qa (Halocene) Qs (Holocene) Tma (Middle Miocene) Timg (Middle Miocene) Tmpm (Late Miocene) Tomt (Oligocene)

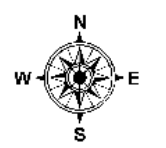

FIGURE 6. Petroleum fields and lineaments. 


\section{REFERENCES}

Amier, R. I. (1991). Coal, Source Rocks, and Hydrocarbons in the South Palembang sub-basin, South Sumatra. The University of Wollongong.

Argakoesoemah, R. M., Raharja, M. W., Maksum, T. F., and Aimar, A. (2005). Telisa Shallow Marine Sandstone as an Emerging Exploration Target in Palembang High, South Sumatra Basin. Proceedings, Indonesian Petroleum Association: The 30th Annual Convention and Exhibition.

Ariani, S., Sihombing, A. Y., Guanawan, I. M., Setiawam, A., Adam, A., and Tarmusi. (2010). Facies and Sandstone Distribution Pattern of ' $X$ ' Sandstone Reservoir in Air Benakat Formation, Sungai Gelam Field, Jambi Subbasin. Indonesian Petroleum Association: The 34th Annual Convention and Exhibition.

Asra, D. S. and Fiter, J. (2005). Correlation between geological properties and production rate at Telisa sandstone in Kaji Field. The 30th HAGI, The 34th IAGI, and the 14th PERHAPI Annual Conference Exhibition. Surabaya.

Barber, A. J., Crow, M. J., and Milsom, J. S. (2005). Sumatra: Geology, Resources, and Tectonic Evolution. Geological Society Memoirs No. 31.

CNBC (2015) Retrieved from Could Indonesia's entry complicate an OPEC production cut

Ekaninggarani, E. and Apricanto, K. (2011). Define a clastic stratigraphic play on 2D dataset with field analogy and geological concept. Proceedings of the 36th HAGI and 40th IAGI Annual Convention and Exhibition. Makassar.

Fedyanto, G. and Sunardi, E. I. ( 2003). Analysis of Sequence Stratigraphy, Lemat Formation to Gumai Formation, GN Field, South Sumatra Basin. The 29th Annual Convention. Jarkata.

Ginger, D. and Fielding, K. (2005). The Petroleum Systems and Future Potential of the South Sumatra Basin. Proceedings Indonesian Petroleum As- sociation: The 30th Annual Convention and Exhibition. Jarkata.

Holis, Z. and Sappie, B. (2012). Fractured Basement Reservoirs Characterization in Central Sumatra Basin, Kotopanjang Area, Ria, Western Indonesia: An Outcrop Analogue Study. American Association of Petroleum Geologists.

Patra, D. H., Noeradi, D., and Subroto, E. (2012). Tectonic Evolution at Musi High and its influence to Gumai Formation as an Active Source Rock at Sopa Field, South Sumatra. Search and Discovery.

Premonowati (2011). Outcrops Conservation of Tanjung Baru or Lower Talang Akar Formation, Baturaja City of Pelembang Area- South Sumatra Basin. Indonesian Sedimentologists Forum.

Pulunggono, A., Haryo, A. S., and Kosuma, C. G. (1992). Pre-Tertiary and Tertiary Fault Systems as a Framework of the Sumatra Basin: A Study of SAR Maps. Proceedings Indonesian Petroleum Association 21st Annual Convention.

Sadarwa, A. W. and Luthfi, N. (2005). Miocene carbonate as the hydrocarbon reservoir in the Jambi area. Proceedings Joint Convention Surabaya HAGI IAGI PERHAPI. The 34th IAGI and the 14th PERHAPI Annual Conference and Exhibition.

Septriandi and Sujarmaitanto (2010). A study of Tectonic and Structural settings in coal basins Indonesia to understand coalification process and implication to coal bed methane (CBM) system. Case study: South Sumatra Basin. Proceedings PIT IAGI Lambok.

Teguh, F., and Agus, H. P. (2011). Jabung block basement- Their characteristics and their economic potential. Proceedings JCM Makassar: The 36th HAGI.

Vilde, D., Rotevatn, A., and Nixon, C. W. (2020). The Relationship between Fluid Flow, Structures, and Depositional Architecture in Sedimentary Rocks: An Example-Based Overview. Geofluids.. 